УДК 342.9

DOI https:// doi.org/10.32837/yuv.v0i1.1659

\title{
М. Новицька,
}

здобувач кафедри адміністративного та господарського права

Запорізького національного університету

\section{«АДМІНІСТРАТИВНЕ ПРАВОПОРУШЕННЯ» ТА СУМІЖНІ ПОНЯТТЯ: АНАЛІЗ СПІВВІДНОШЕННЯ}

Дослідження сутності адміністративних правопорушень, їх класифікація за ступенем суспільної небезпеки має надзвичайну важливість як для розвитку вітчизняної юридичної галузевої науки, так і для ефективного правозастосування. Загальнотеоретична характеристика дозволяє визначити конкретні види відповідних правопорушень, розкрити їх поняття, охарактеризувати істотні ознаки, які відображають сутність і зміст таких правопорушень, з'ясувати специфічні особливості, спільні та відмінні риси, а також їх нормативне закріплення.

3 огляду на істотний інтерес в адміністративно-правовій науці до проблематики адміністративних правопорушень значне коло питань вже досліджувалося, проте окремі аспекти розуміння сутності й ознак адміністративного правопорушення досі лишаються актуальними. Проблематиці поняття і специфіки адміністративного правопорушення в сучасній адміністративно-правовій, у т. ч. адміністративно-деліктній доктрині присвячено достатньо уваги, проте слід з'ясувати співвідношення поняття «адміністративне правопорушення» із суміжними поняттями. У зв'язку із цим необхідно провести детальний аналіз теоретичних розробок, присвячених проблемам використання термінології у відповідній сфері для однозначного правильного розуміння такого юридичного явища, як «адміністративне правопорушення» з урахуванням ступеня його суспільної небезпеки та забезпечення якості нормативно-правової бази.
Значний інтерес у науковому середовищі до категорії «адміністративне правопорушення» викликає питання його співвідношення зі спорідненими поняттями, такими як «адміністративний проступок», «адміністративний делікт», а також їх відмінність від понять «кримінальне правопорушення», «кримінальний проступок», про що свідчать численні доктринальні джерела, монографічні праці з відповідної адміністративно-правової тематики.

Так, Ю.П. Битяк вважає, що адміністративне правопорушення (проступок) - це насамперед діяння, поведінка, вчинок, акт зовнішнього вираження ставлення особи до реальної дійсності, інших людей, держави, суспільства [1, с. 123]. Вчений використовуе поняття «адміністративне правопорушення» й «адміністративний проступок» як синоніми, вважає, що вони не мають суттєвих відмінностей, і останнє не $є$ особливим різновидом адміністративних правопорушень [2, с. 174-175]. В.Б. Авер'янов, навпаки, стверджує, що поняття «адміністративного проступку» має специфічний зміст, який виокремлює його з усієї сукупності адміністративних правопорушень, тобто співвідносить адміністративне правопорушення й адміністративний проступок як частину і ціле [3, с. 432]. На думку А.С. Васильєва, «адміністративні правопорушення» - специфічний різновид правопорушень, за здійснення яких застосовуються заходи адміністративної відповідальності. Тому для уникнення термінологічної плутанини, автор пропонує іменувати іх більш 
точно - «адміністративними проступками» [4, с. 33-34]. В.К. Колпаков справедливо зауважує, що зазвичай у сучасній літературі аналіз понять спирається на суто лінгвістично-кримінологічну трактовку без урахування історичних коренів появи у праві та законодавстві терміна «проступок» [5, с. 162]. Вчений-адміністративіст перший хто порушує проблему генези адміністративного проступку у вітчизняній адміністративно-правовій науці, всебічно досліджує історико-правову природу адміністративного (управлінського) правопорушення й адміністративного проступку (делікту), ніїх онтологічні та гносеологічні властивості. Автор наголошує на тому, що доктринальні й нормативні поняття i визначення галузевого рівня, в яких розкривається сутність, зміст і обсяг адміністративного проступку, можуть бути адекватно інтерпретовані тільки у разі їхньої органічної взаємодії із системою понять загальної теорії правопорушення (делікту) [5, с. 165]. Однак слід підкреслити, що головним приводом наукових суперечок є ототожнення законодавцем понять «адміністративний проступок» i «адміністративне правопорушення», це привело дослідників до висновку, що адміністративні проступки є специфічним різновидом правопорушень, за вчинення яких застосовуються заходи адміністративної відповідальності. Так, наприклад, А.Т. Комзюк вважає, що поняття «адміністративне правопорушення» й «адміністративний проступок» не однакові, через те що «адміністративне правопорушення $€$ порушенням будь-якої адміністративно-правової норми незалежно від того, чи передбачено за це відповідальність, а адміністративний проступок слід розглядати як різновид адміністративного правопорушення, за який встановлено адміністративну відповідальність» [6, с. 15]. Зазначену думку впроваджує Т.О. Коломоєць, зазначаючи, що «адміністративним правопорушенням слід вважати будьяке порушення норм адміністратив- ного права, тоді як адміністративним проступком $€$ протиправне вчинення діянь, за які законодавством передбачено накладення адміністративного стягнення» [7, с. 35-36]. Науковець обгрунтовано доводить необхідність застосування терміна «адміністративний проступок». Ії думку підтримують В.С. Стефанюк [8, с. 12], K.А. Бугайчук [9, с. 7], О.І. Миколенко [10, с. 38], В.М. Бевзенко [11, с. 201] та ін. Так, О.А. Банчук, І.Б. Коліушко, підтримуючи переконання авторів проекту Концепції реформи адміністративного права України [12], звертають увагу на те, що чинний Кодекс України про адміністративні правопорушення оперує поняттями «адміністративне правопорушення» Й «адміністративний проступок» як рівнозначними та вважають це неправильним, пропонують відмовитися від звуженого використання терміна «адміністративне правопорушення» i наполягають на доцільності залишити лише поняття «адміністративний проступок», перейменувавши сам законодавчий акт на Кодекс Украіни про адміністративні проступки [13, с. 32]. Аналогічне співвідношення подають С.В. Ківалов і Л.Р. Біла, вважаючи, що поняття «адміністративне правопорушення» за своєю сутністю $€$ набагато ширшим, ніж поняття «адміністративний проступок», оскільки воно включає в себе всі протиправні діï у сфері державного управління, натомість адміністративний проступок включає в себе тільки ті протиправні діï, за які настає адміністративна відповідальність [14, с. 303]. Таким чином, серед вчених-адміністративістів слід відзначити наявність прихильників використання поняття саме «адміністративний проступок».

У свою чергу, опоненти запровадження в національну правову систему поняття «адміністративного проступку» зазначають, що така термінологія суперечить положенням Конституції Украіни (п. 22 ч. 1 ст. 92), оскільки вони нормативно не містять будь-які інші види протиправних діянь, окрім зло- 
чинів і правопорушень: «Виключно законами України визначаються <..> діяння, які $€$ злочинами, адміністративними або дисциплінарними правопорушеннями, та відповідальність за них», тобто в документі, що має найвищу юридичну силу, йдеться саме про адміністративні правопорушення, а не про адміністративні проступки [15]. Д.М. Лук'янець вважає, що адміністративне правопорушення (проступок) $€$ фактичною підставою адміністративної відповідальності. Характеризуючи елементи складу адміністративного правопорушення (проступку), автор не розмежовує поняття «адміністративне правопорушення» й «адміністративний проступок», поперемінно їх використовує [16, с. 45-49]. Хоча вважає, що більш доцільним було б формально їх відділити та визначити «проступок» як суспільно-небезпечне діяння, яке порушує норми адміністративного права, за котре передбачена адміністративна відповідальність [17, с. 318]. Т.О. Коломоєць, В.К. Колпаков, досліджуючи проблеми адміністративно-деліктних відносин, наголошують, що «адміністративні правопорушення», «адміністративні проступки», «адміністративні делікти» - це діяння, вчинені відповідним суб'єктом, які порушують встановлені чинним законодавством заборони і тягнуть за собою покарання у вигляді адміністративних стягнень, визначені законом [18, с. 31]. O.I. Остапенко, характеризуючи сутність делікту (адміністративного правопорушення), зіставляє його 3 «адміністративним проступком», тим самим ототожнюючи усі три поняття: «адміністративне правопорушення», «адміністративний проступок» і «адміністративний делікт». Автор пропонує законодавцю таку дефініцію адміністративного делікту: «Це передбачені законом суспільно шкідливі (небезпечні), протиправні, винні діï чи бездіяльність, вчинені особою у конкретному місці за певних умов під час посягання на суспільні відносини, які охороняються законом» [19, с. 169]. Делікт (від лат. delictum) за енцикло- педичним трактуванням - це правопорушення, незаконна дія, проступок, злочин. У римському праві делікт тлумачиться як заподіяння шкоди іншій особі, ї сім’і або майну, порушення правового припису або заборони. Як наслідок, за вчинення делікту особу притягували до адміністративної відповідальності [20, с. 55]. У теорії держави та права деліктом визнається правопорушення як суспільно небезпечне винне протиправне діяння деліктоздатного суб'єкта, за яке чинне законодавство передбачає юридичну відповідальність [21, с. 163]. За словниковим визначенням «порушення» означає «відхилення від правил, відступ від законів»; порушувати - «робити що-небудь всупереч наказам, закону» [22, с. 1074]. Проступок - «вчинок, що порушує які-небудь норми, правила поведінки, загальноприйнятий порядок; провина» [23, с. 598]. Правопорушення - це «свідомий вольовий акт суспільно небезпечної протиправної поведінки» [24, с. 155]. Термін «правопорушення» за своїм змістом об'ємний і в широкому сенсі слова - це антигромадське протиправне діяння, що заподіює шкоду i карається законом. Воно об'єднує цивільні, адміністративні, дисциплінарні та найбільш небезпечний вид кримінальні правопорушення. Правопорушення за своєю суттю охоплюють всі діяння, що порушують встановлений законом (у широкому його розумінні) порядок реалізації прав, свобод, законних інтересів і їх гарантій, а також здійснення обов'язків. Так, Б.О. Логвиненко вважає, що проступки мають ототожнюватися з існуванням заборонних норм, які повинні чітко визначити діяння, що визнаються суспільно шкідливими та суспільно небезпечними. Наполягає на необхідності легального закріплення понять «правопорушення» та «проступок», а це гарантує дієві механізми, пов'язані з ефективною реалізацією громадянами їх прав, свобод та інтересів, а також убезпечить як окрему взяту особистість, так і суспільство загалом від суспільно шкідли- 
вих подій, зумовлених протиправними діями суб'єктів [25, с. 10].

Слід зазначити, що поняття «делікт» офіційно у законодавстві України не застосовується, але в науково-правовій літературі та на практиці вживається досить часто у широкому й вузькому сенсах. У широкому розумінні деліктом визнається будь-яка недозволена дія, правопорушення, що має наслідком застосування покарання до особи, котра його вчинила. Вузьке розуміння передбачає поділ деліктів за сферою ix виникнення та реалізації на приватноправові та публічно-правові, серед останніх виділяють адміністративні делікти. Тобто за загальним значенням делікт - це правопорушення, протиправне діяння, а адміністративний делікт $є$ різновидом таких діянь.

Науковці також розмежовують «адміністративні проступки» та «кримінальні проступки», де перші є правопорушеннями у сфері публічного управління, а другі - правопорушеннями в інших сферах суспільного життя, що охороняються нормами адміністративного права. Так, наприклад, В.О. Туляков визначає кримінальний проступок за своїми властивостями як «проміжне діяння» між злочином і правопорушенням, за скоєння якого настає кримінальна відповідальність, не пов'язана із заходами виправно-трудового впливу, та який порушує «горизонтальні відносини» управлінського та / або публічно-договірного характеру, закріплене в нормах позитивного права, й опосередковано посягає на природні права людини [26, с. 389]. Н.Ф. Кузнєцова під кримінальним проступком розуміє «умисне чи необережне малозначне за своїм характером і ступенем суспільної небезпеки діяння» [27, с. 48]. Н.А. Мирошниченко пропонує таке визначення кримінального проступку: «діяння, що має знижений ступінь суспільної небезпеки, за яке може бути призначено покарання, не пов'язане 3 позбавленням і обмеженням волі (штраф, позбавлення права обіймати певні посади чи займатися певною діяльністю, громадські роботи, виправні роботи, арешт) і яке не тягне за собою судимість» [28, с. 334]. M.I. Хавронюк виділяе такі критерії відмежування адміністративних проступків від кримінальних: тяжкість наслідків; суспільну небезпеку; форму вини; повторність вчиненого діяння тощо [29]. I.M. Копотун, M.В. Рудик вважають, що критеріями для визначення деяких адміністративних правопорушень як кримінальних проступків можуть стати: вчинення проступків поза сферою управління; ступінь їх небезпечності для суспільних відносин; вид стягнення [30, с. 253]. Р.Г. Пєсцов зауважує, що адміністративні та кримінальні проступки повинні відрізнятися за видом і суворістю стягнень [31, с. 201]. Крім того, як зазначає Г.В. Федотова, до критеріїв відмежування злочину, кри-

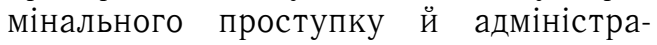
тивного правопорушення належить різна процесуальна форма досудового та судового розгляду матеріалів щодо цих діянь і різні суб'єкти процесуальної діяльності [32, с. 94]. І.П. Голосніченко вважає, що проступки доцільно розділити на адміністративні та кримінальні залежно від ступеня завданої ними шкоди суспільним відносинам, виду об'єкта правопорушення, суб'єкта юрисдикції, тяжкості та виду стягнень, що передбачаються за їх вчинення, суб'єкта правопорушення [33, с. 81]. Отже, із наведеного можна констатувати, що погляди науковців на розмежування адміністративного проступку i кримінального проступку не збігаються, кожен пропонує власні критерії, тому в цілях забезпечення адекватної реакції законодавця на вчинення відповідних протиправних діянь нагальною потребою $є$ чітке нормативно-правове вирішення цієї проблеми.

Узагальнюючи думки вчених-адміністративістів, можна констатувати, що термін «проступок» здебільшого використовується як синонім при визначенні поняття «адміністративне правопорушення», без чіткого змістовного розмежування, тобто представники 


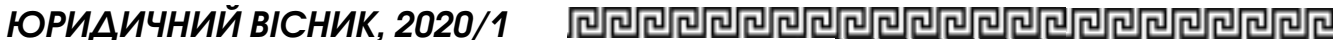

адміністративно-правової науки загалом сприймають як синоніми терміни «адміністративні правопорушення», «адміністративні проступки», «адміністративні делікти». У фахових наукових роботах з адміністративного права і процесу наведені визначення дефініцій «адміністративне правопорушення», «адміністративний проступок» зазвичай мають дослідницький характер. Теоретичні позиції є логічними та чітко обгрунтованими, однак, на думку багатьох вчених-адміністративістів, ототожнення цих термінів є застарілим і суперечить загальним досягненням сучасної юридичної науки. Таким чином, поділяючи позицію науковців, згідно 3 якою адміністративне правопорушення (проступок) є діянням, вчиненим відповідним суб'єктом, що порушує встановлені чинним законодавством заборони i тягне за собою покарання у вигляді адміністративних стягнень, визначених законом, поняття «адміністративне правопорушення» й «адміністративний проступок» можна застосовувати як синоніми, оскільки таку позицію зафіксовано і законодавцем.

У статті проведено правовий аналіз співвідношення поняття «адміністративне правопорушення» із суміжними поняттями. Відзначено істотний інтерес в адміністративно-правовій науці до проблематики адміністративних правопорушень загалом. З’ясовано, що значне коло питань вже досліджувалося науковияями, проте окремі аспекти розуміння сутності й ознак адміністративного правопорушення, а також його співвідношення із суміжними поняттями досі лишаються актуальними. Обгрунтовано, що значний інтерес у науковому середовищі до категорії «адміністративне правопорушення» становить питання його співвідношення зі спорідненими поняттями, такими як «адміністративний проступок», «адміністративний делікт», а також їх відмінність від понять «кримінальне правопорушен- ня», «кримінальний проступок», про що свідчать численні доктринальні джерела, монографічні праці з відповідної адміністративно-правової тематики. Дослідження такого співвідношення дозволяе відобразити весь ресурс $i$ зміст поняття "адміністративне правопорушення», а також уникати термінологічної плутанини. Проаналізовано діаметрально протилежні позиціi вчених, фахівців у сфері адміністративного, в т. ч. адміністративно-деліктного права щодо співвідношення поняття "адміністративне правопорушення» із сумінними поняттями. Звернуто увагу на положення нормативно-правових актів щодо закріплення офінійних дефініиій. Акцентовано на тому, що погляди науковців на розмежування адміністративного проступку $i$ кримінального проступку не збігаються, кожен пропонуе власні критеріі, тому з метою забезпечення адекватної реакції законодавия на вчинення відповідних протиправних діянь нагальною потребою є чітке нормативно-правове вирішення иієї проблеми. Зроблено відповідні висновки щодо співвідношення поняття «адміністративне правопорушення» із суміжними поняттями.

Ключові слова: адміністративне правопорушення, адміністративний проступок, адміністративний делікт, кримінальне правопорушення, кримінальний проступок.

Novytska $M$. "Administrative offense" and related concepts: ratio analysis

The article analyzes the legal analysis of the relation between the term "administrative offense" and related concepts. Significant interest in the field of administrative law to the problems of administrative offenses in general was noted. It has been established that a considerable number of issues have already been investigated by scientists, but some aspects of 
understanding the nature and features of an administrative offense, as well as its relation with related concepts remain relevant in the present day. It is substantiated that significant interest in the scientific environment in the category of "administrative offense" is the question of its relation to related concepts, such as "administrative offense", "administrative tort", as well as their difference from the concepts of "criminal offense", "criminal offense", as evidenced by numerous doctrinal sources, monographs on relevant administrative and legal subjects. The study of this relationship allows us to reflect the whole resource and content of the concept of "administrative offense", as well as to avoid terminological confusion. The diametrically opposite positions of scientists and experts in the field of administrative, including the administrative-tort law regarding the relation of the concept of "administrative offense" with related concepts are analyzed. Attention is drawn to the provisions of legal acts on the consolidation of official definitions. Attention is drawn to the fact that the views of scientists on the delineation of administrative misconduct and criminal misconduct do not coincide, and each offers its own criteria, so in order to ensure an adequate response of the legislator to the perpetration of the relevant unlawful acts, a clear regulatory and legal solution to this problem is urgent. The relevant conclusions are drawn regarding the relation between the term "administrative offense" and related concepts.

Key words: administrative offense, administrative tort, administrative delict, criminal offense, criminal offense.

\section{Література}

1. Административное право Украинь (Общая часть) : учебное пособие / Ю.П. Битяк, Б.В. Зуй. Харьков : Одиссей, 1999. 224 c.

2. Адміністративне право України : підручник / Ю.П. Битяк, В.М. Гаращук,
О.В. Дьяченко та ін. ; за ред. Ю. П. Битяка. Київ : Юрінком Iнтер, 2007. 544 c.

3. Адміністративне право України. Академічний курс : підручник : у 2 т. T. 1. Загальна частина / ред. В.Б. Авер'янов. Київ : «Юридична думка», 2004. 584 с.

4. Кодекс Украины об административных правонарушениях : Научно-практический комментарий / под общ. ред. А.С. Васильев ; отв. за вып. С.В. Карплюк. Харьков : ООО «Одиссей», 2000. 1008 c.

5. Колпаков В.К. Адміністративно-деліктний правовий феномен : монографія. Київ : Юрінком Інтер, 2004. 528 с.

6. Aдміністративна відповідальність в Україні : навчальний посібник / за заг. ред. А.Т. Комзюка. Харків : Ун-m внутр. справ, 2000. 99 c.

7. Коломоєиь Т.О. Штрафи за законодавством про адміністративні правопорушення: дис. ... канд. юрид. наук : 12.00.07. Запоріжж, 1999. 196 с.

8. Стефанюк В.С. Правова обумовленість запровадження адміністративної юстиції в Україні : автореф. дис. ... канд. юрид. наук : 12.00.07. Київський національний ун-т ім. Тараса Шевченка. Київ, 2000. $20 \mathrm{c}$.

9. Бугайчук K.А. Адміністративні проступки: сутність та організаційно-правові заходи їх профілактики : автореф. дис. ... канд. юрид. наук : 12.00.07 / Національний університет внутрішніх справ. Харків, 2002. 19 c.

10. Миколенко А.И. Административньй процесс и административная ответственность в Украине : учебное пособие. Харьков : «Одиссей», 2004. 272 с.

11.Бевзенко В.М. Правові та лінгвістичні аспекти співвідношення понять «адміністративний проступок» та «адміністративне правопорушення». університетські наукові записки. 2005. № 4. C. 199-202.

12. Про Концепцію реформи адміністративного права України : Проект Постанови Верховної Ради України № 6054 від 11 вересня 2000 p. URL: http: / / 1.c1.rada.gov.ua/pls / zweb2 / webproc4_2?skl=4\&pf3516=6054.

13. Коліушко І.Б., Банчук О.А. Поняття адміністративної відповідальності та адміністративного правопорушення в сучасному українському праві. Право України. 2008. № 4. C. 31-36. URL: https:// www.pravo.org.ua/ua/news / 2580 -.

14. Ківалов С.В., Біла Л.Р. Адміністративне право України : навчально-методич- 


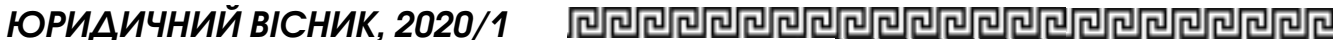

ний посібник. Одеса : Юридична література, 2002. 312 c.

15. Висновок Головного науково-експертного управління Апарату Верховноі Ради України на проект Кодексу України про адміністративні проступки (реєстраційний № 5558 від 26 травня 2004 р.). URL: http: / / w1.c1.rada.gov.ua/pls / zweb2/webp roc4_2?id $=\& p f 3516=5558 \& s k l=5$.

16. Лук'янещь Д.М. Інститут адміністративної відповідальності: проблеми розвитку : монографія. Київ : Iн-т держави i права ім. В.М. Корецького НАН України, 2001. $220 \mathrm{c}$

17. Лук'янець Д.м. Напрями реформування адміністративно-деліктного законодавства. Правова держава. 2001. № 12. С. 318-333.

18. Вступ до навчального курсу «Адміністративне право України»: текст лекцій / T.О. Коломоєць, В.К. Колпаков. Київ: Iн Юpe, 2014. 240 c.

19. Oстапенко O.I. Адміністративна деліктологія: соціально-правовий феномен i проблеми розвитку : монографія. Львів : ЛIВС при НАВСУ, 1995. 312 с.

20. Юридична енииклопедія : в $6 \mathrm{~m}$. / редкол. : Ю.С. Шемшученко та ін. Київ : «Укр. Енииклопедія», 1998. T. 2. 744 с.

21. Кириченко В.М., Куракін О.М. Теорія держави і права: модульний курс : навчальний посібник. Київ: Центр навчальної літератури, 2010. 264 c.

22. Великий тлумачний словник сучасної української мови / уклад. та голов. ред. В.Т. Бусел. Київ; Ірпінь : Перун, 2005. VIII. 1728 c.

23. Новий тлумачний словник української мови : у 4 m. / уклад. : В. Яременко, О. Сліпушко. Київ : АКОНІт. т. 3. 1999. $928 \mathrm{c}$.

24. Малеин Н.С. Правонарушение: понятие, причинь, ответственность. Москва: Юрид. лит., 1985. 192 с.
25. Логвиненко Б.О. Кваліфікація адміністративних правопорушень: Конспект лекцій. Дніпропетровський державний університет внутрішніх справ. Дніпро. 2016. $18 \mathrm{c}$.

26. Туляков B.О., Дмитрук М.М. Kaтегорія кримінального проступку в правовій доктрині. Актуальні проблеми держави $i$ права. 2009. № 45. С. 384-390.

27. Кузнецова Н.Ф. Классификащия преступлений. Советское государство и право. 1967. № 6. С. 48-51.

28. Мирошниченко Н.А. Визначення проступку та злочину в кримінальному праві України. Актуальні проблеми політики. 2014. № 51. C. 331-336.

29. Хавронюк М.I. Поняття злочинного діяння за законодавством європейських країн. Підприємництво, господарство $і$ право. 2004. № 9. С. 112-117.

30. Копотун I.M., Рудик М.В. Проблеми відмежування правопорушень від злочинів у сфері громадського порядку. Науковий вісник Дніпропетровського державного університету внутрішніх справ. 2014. № 4. C. 248-256.

31. Пєсиов Р.Г. Запровадження інституту кримінальних проступків у кримінальному законодавстві України. Право. НПУ імені М.П. Драгоманова. 2014. № 26. С. 198-203.

32. Федотова Г.В. Критерії відмежування кримінального проступку від злочину та адміністративного правопорушення. Науковий вісник Ужгородського національного університету. 2016. № 38. C. 91-94.

33. Голосніченко І.П. До проблеми запровадження в Україні кримінального проступку та відмежування його від адміністративного правопорушення. Вісник Національного технічного університету України «Київський політехнічний інститут». Політологія. Соціологія. Право. 2014. № 1. C. $80-83$. 